\title{
HUBUNGAN STATUS GIZI DAN MOTIVASI BERPRESTASI DENGAN TINGKAT KONDISI FISIK SISWA PPLP CABANG PENCAK SILAT SUMATERA BARAT
}

\author{
Suwirman, Nurul Ihsan, Sepriadi ${ }^{4)}$
}

\begin{abstract}
ABSTRAK
Tujuan penelitian ini adalah untuk melihat hubungan status gizi dan motivasi berprestasi terhadap tingkat kondisi fisik Siswa PPLP Cabang Pencak Silat Sumatera Barat. Penelitian yang diteliti tergolong kedalam jenis penelitian deskriptif dengan pendekatan korelasional. Subjek penelitian ini adalah siswa PPLP Sumatera Barat cabang pencak silat yang berjumlah 20 orang. Data kondisi fisik diukur dengan standing board jump untuk mengukur daya ledak otot tungkai, shuttle run mengukur kelincahan, push-up mengukur daya tahan kekuatan otot lengan, sit-up mengukur daya tahan kekuatan otot perut, dan bleep test mengukur daya tahan aerobik. Data status gizi di ukur dengan IMT (Indkes Massa Tubuh). Data motivasi berprestasi diukur dengan angket motivasi berprestasi. Teknik analisa data yang digunakan adalah analisis korelasi product moment. Hasil penelitian ini adalah: 1) Terdapat Hubungan status gizi terhadap tingkat kondisi fisik Siswa PPLP Cabang Pencak Silat Sumatera Barat sebesar 20,97\%. 2) Terdapat Hubungan motivasi berprestasi terhadap tingkat kondisi fisik Siswa PPLP Cabang Pencak Silat Sumatera Barat sebesar 26,18\%.
\end{abstract}

Kata Kunci: Status Gizi, Kondisi Fisik, Motivasi Berprestasi

\section{ABSTRACT}

The purpose of this study is to see the relationship of nutritional status and achievement motivation to the level of physical condition of PPLP Student Branch of Pencak Silat West Sumatra. The research studied is classified into the type of descriptive research with correlational approach. The subject of this research is the students of PPLP West Sumatra pencak silat branch amounting to 20 people. Physical condition data measured with standing board jump to measure explosive muscle limb power, shuttle run measure agility, push-ups measure endurance of arm muscle strength, sit-up measure endurance of abdominal muscle strength, and bleep test measure aerobic endurance. Nutritional status data is measured by BMI (Body Mass Index). The data of achievement motivation is measured by questionnaire of achievement motivation. Data analysis technique used is product moment correlation analysis. The results of this study are: 1) There is a relationship of nutritional status to the level of physical condition of PPLP Student Branch of Pencak Silat West Sumatera by 20.97\%. 2) There is a relationship of achievement motivation to the level of physical condition of PPLP Student Branch of Pencak Silat West Sumatra by 26.18\%.

\section{Keywords: Nutrition Status, Physical Condition, Achievement Motivation}

4) Suwirman. Saat ini Dosen Jurusan Pendidikan Olahraga Fakultas Ilmu Keolahragaan Universitas Negeri Padang

4) Nurul Ihsan. Saat ini Dosen Jurusan Pendidikan Olahraga Fakultas Ilmu Keolahragaan Universitas Negeri Padang

4) Sepriadi. Saat ini Dosen Jurusan Pendidikan Olahraga Fakultas Ilmu Keolahragaan Universitas Negeri Padang 


\section{PENDAHULUAN}

Pencak silat merupakan salah satu seni beladiri bangsa Indonesia yang telah lama berkembang di seluruh pelosok tanah air, bahkan ke manca Negara. Peminat pencak silat bukan hanya terbatas pada usia-usia tertentu saja, melainkan telah diminati oleh berbagai jenjang usia, mulai dari anak-anak, remaja, dewasa hingga orang tua. Pada saat sekarang, pencak silat telah masuk dalam kurikulum pendidikan yang termasuk dalam aspek permainan dan olahraga.

Pencak silat disamping beladiri, juga merupakan olahraga prestasi dan telah di pertandingan dalam berbagai even olahraga. Pencak silat telah dipertandingkan mulai tingkat daerah sampai ke tingkat nasional dan internasional. Sebagai olahraga prestasi, dalam pertandingan pencak silat dibutuhkan beberapa komponen yang harus dimiliki oleh atletnya. Salah satu adalah kondisi fisik. Hal ini sesuai dengan Syafruddin (2011) yang menyatakan bahwa kemampuan seorang atlit pada saat pertandingan atau kompetisi salah satunya dipengaruhi oleh faktor kondisi fisik.

Kondisi fisik merupakan salah satu faktor yang sangat penting karena untuk dapat melakukan teknik ini dengan baik maka juga harus didukung dengan kondisi fisik yang baik pula. Dalam pencak silat diperlukan berbagai unsur kondisi fisik diantaranya adalah daya ledak, daya tahan kekuatan, kelincahan dan daya tahan (Ihsan. 2018).

Selama ini, kondisi fisik seorang atlet selalu dikaitkan dengan factor latihan. Atlet anak memiliki kondisi fisik yang baik apabila dilatih secara baik dan terprogram. Namun belum ada suatu studi yang mengkaitkannya dengan factor lain seperti motivasi berprestasi dan status gizi yang dimiliki atletnya.

Oleh karena itu dalam penelitian ini akan dilihat keterkaitan antara status gizi dan motivasi berprestasi dengan kondisi fisik. Di samping itu akan dilihat seberapa besar Hubungan yang diberikan olah kedua unsure ini terhadap kondisi fisik atlet.

\section{Kondisi Fisik}

Untuk mewujudkan prestasi yang baik, kondisi fisik merupakan suatu hal yang sangat diperlukan. Sajoto (1995:57) berpendapat "kondisi fisik adalah salah satu persyaratan yang sangat diperlukan dalam setiap usaha peningkatan prestasi seorang

4) Suwirman. Saat ini Dosen Jurusan Pendidikan Olahraga Fakultas Ilmu Keolahragaan Universitas Negeri Padang

4) Nurul Ihsan. Saat ini Dosen Jurusan Pendidikan Olahraga Fakultas Ilmu Keolahragaan Universitas Negeri Padang

4) Sepriadi. Saat ini Dosen Jurusan Pendidikan Olahraga Fakultas Ilmu Keolahragaan Universitas Negeri Padang 
atlet bahkan dikatakan dasar landasan titik tolak sesuatu awalan olahraga prestasi”. Hal ini berarti bahwa kondisi fisik akan mempengaruhi dan menjadi faktor utama dalam menentukan prestasi dari seorang atlit pencak silat (Nurul, 2017).

Berdasarkan analisis situasi dalam pertandingan pencak silat, maka beberapa komponen kondisi fisik yang diperlukan oleh atlit pencak silat adalah daya tahan, kelincahan, daya ledak otot tungkai:

1) Daya Ledak Otot Tungkai (Power)

Daya ledak merupakan salah satu dari komponen biomotorik yang penting dalam kegiatan olahraga. Karena daya ledak menentukan seberapa keras dapat orang memukul, seberapa jauh melempar, seberapa tinggi melompat, seberapa cepat berlari dan sebagainya.

Daya ledak sering disebut juga power, karena proses kerjanya anaerobik yang memerlukan waktu tercepat dan tenanga yang kuat. Semuanya dalam keadaan sewaktu-waktu dapat meledak secara maksimal dalam upaya memperoleh kekuatan secara baik dan benar. Daya ledak adalah kemampuan otot untuk mengarahkan kekuatan maksimal dalam waktu yang amat singkat.

Jadi dapat ditarik kesimpulan bahwa daya ledak otot merupakan kemampuan untuk menampilkan kekuatan maksimum dan kecepatan maksimum secara eksplosif dalam waktu cepat dan singkat untukmencapai tujuan yang dikehendaki, sehingga otot yang menampilkan gerakan eksplosif sangat kuat dan cepat dalam berkontraksi. Dalam pencak silat, daya ledak otot tungkai digunakan untuk tolakan kaki ketika melakukan tendangan ke arah lawan.

2) Kelincahan (Agility)

Kelincahan (agilitas) adalah kemampuan seseorang untuk dapat mengubah arah dengan cepat dan tepat pada waktu bergerak tanpa kehilangan keseimbangan. Kelincahan berkaitan erat dengan tingkat kelentukan. Tanpa kelentukan yang baik seseorang tak dapat bergerak dengan lincah. Selain itu, faktor keseimbangan sangat berpengaruh terhadap kemampuan kelincahan seseorang (Nurul, 2014).

4) Suwirman. Saat ini Dosen Jurusan Pendidikan Olahraga Fakultas Ilmu Keolahragaan Universitas Negeri Padang

4) Nurul Ihsan. Saat ini Dosen Jurusan Pendidikan Olahraga Fakultas Ilmu Keolahragaan Universitas Negeri Padang

4) Sepriadi. Saat ini Dosen Jurusan Pendidikan Olahraga Fakultas Ilmu Keolahragaan Universitas Negeri Padang 
Kelincahan adalah kemampuan seseorang untuk merubah posisi atau arah secepat mungkin sesuai dengan situasi yang dihadapi dan dikehendaki. Selanjutnya menurut Toho dan Gusril (2004:81) mengatakan bahwa: "kelincahan merupakan kemampuan seseorang mengubah arah dan posisi tubuh dengan cepat dan tepat pada waktu bergerak dan satu titik ke titik yang lain”.

Kelincahan akan dipengaruhi oleh beberapa komponen kondisi fisik lainnya: kekuatan, keseimbangan, kelentukan dan koordinasi. Maksudnya adalah kombinasi dari komponen kondisi fisik yang saling terkait. Suharno (1985:33) menjelaskan bahwa fakto-faktor penentu atau tidaknya kelincahan adalah: kecepatan reaksi, kemampuan berorientasi terhadap masah yang dihadapi, kemampuan mengatur keseimbangan dan kemampuan mengerem gerakan-gerakan motorik.

3) Daya Tahan Kekuatan otot lengan (Strength Endurance)

Daya tahan kekuatan (strength endurance) adalah kemampuaan sistem otot dan saraf untuk menghasilkan kekuatan secara berulang-ulang dalam priode waktu yang lama. Daya tahan kekuatan otot lengan ini harus dimiliki agar pesilat dapat memukul dan membanting secara berulang selama pertandingan

4) Daya Tahan (Endurance)

Secara sederhana dapat diartikan dengan kemampun menghadapi kelelahan, secara defenitif daya tahan merupakan kemampuan organisme tubuh untuk mengatasi kelelahan yang disebabkan oleh pembebanan dalam waktu yang lama. Weineek dalam Syafruddin (2011:68) mengartikan Daya tahan sebagai kemampuan atlet mengatasi kelelahan fisik dan psikis (mental). Daya tahan merupakan salah satu elemen kondisi fisik yang terpenting, karna merupakan basis dan elemenelemen kondisi fisik yang lain.

Daya tahan adalah suatu kemampuan tubuh untuk bekerja dalam waktu lama tanpa mengalami kelelahan setelah menyelesaikan pekerjaan tersebut. Daya tahan umumnya di artikan sebagai ketahanan terhadap kelelahan dan kemampuan pemulihan segera mengalami kelelahan. Daya tahan yang tinggi dapat

4) Suwirman. Saat ini Dosen Jurusan Pendidikan Olahraga Fakultas Ilmu Keolahragaan Universitas Negeri Padang

4) Nurul Ihsan. Saat ini Dosen Jurusan Pendidikan Olahraga Fakultas Ilmu Keolahragaan Universitas Negeri Padang

4) Sepriadi. Saat ini Dosen Jurusan Pendidikan Olahraga Fakultas Ilmu Keolahragaan Universitas Negeri Padang 
mempertahankan penampilan dalam jangka waktu yang relatif lama secara terus menerus.

Secara fisiologis daya tahan berhubungan dengan kemampuan jantung dan organ pernafasan. Kemampuan jantung dapat menambah volume satu menit (cardiac output) untuk menghantarkan oksigen dan zat-zat yang dipergunakan dalam sistem metabolik. Menurut Namawi (2006:38) tinggi rendahnya daya tahan seseorang akan ditentukan oleh tinggi rendahnya VO2 Max seseorang. VO2 Max adalah volume oksigen disebut juga sebagai kapasitas aerobik, yaitu kemampuan tubuh mengkonsumsi oksigen secara maksimal permenit. VO2 Max ditunjuk oleh kemampuan paru-paru sebagai organ yang menyediakan oksigen kualitas darah (hemoglobin) yang akan mengikat dan membawa oksigen keseluruh tubuh, jantung sebagai organ yang memompa darah keseluruh tubuh, pembuluh darah (sirkulasi) yang akan menyalurkan darah keseluruh tubuh dan otot rangka sebagi salah satu organ tubuh yang akan memakai oksigen untuk proses oksidasi bahan makanan sehingga menghasikan energi.

Dalam setiap pertandingan seorang atlet harus memiliki VO2 Max yang baik, maka masa pemulihan akan cepat dilakukan oleh tubuh sehingga untuk melakukan pertandingan yg lama tubuh masih mampu melakukan berbagai macam serangan dengan kontraksi yang tinggi, jika atlet tidak memiliki VO2 Max yang baik maka dalam pemulihan akan lambat dilakukan oleh tubuh, sehungga pada babak berikutnya, kemampuan atlet akan menurun, sehingga prestasi maksimal tidak akan tercapai.

\section{Status Gizi}

Menurut Toho (2004:92) "status gizi adalah suatu kondisi dari setiap individu yang dipengaruhi oleh penggunaan zat makanan, dan dapat di bedakan antara status gizi buruk, kurang, baik dan lebih". Menurut Endang (2007:14) “Zat gizi adalah bahan dasar yang menyusun bahan makanan”. Suhardjo (2008:55) juga berpendapat "status gizi adalah keadaan kesehatan individu-individu atau kelompok-kelompok yang ditentukan oleh derajat kebutuhan fisik akan energi dan

4) Suwirman. Saat ini Dosen Jurusan Pendidikan Olahraga Fakultas Ilmu Keolahragaan Universitas Negeri Padang

4) Nurul Ihsan. Saat ini Dosen Jurusan Pendidikan Olahraga Fakultas Ilmu Keolahragaan Universitas Negeri Padang

4) Sepriadi. Saat ini Dosen Jurusan Pendidikan Olahraga Fakultas Ilmu Keolahragaan Universitas Negeri Padang 
zat-zat gizi lain yang di peroleh dari pangan dan makanan yang dampak fisiknya di ukur secara antropometri”".

Gizi juga dibutuhkan bagi pertumbuhan tubuh bagi seorang anak karena dengan gizi maka akan terjadi pertumbuhan tulang dan jaringan tubuh yang baik (Sepriadi, 2017:203). Departemen Kesehatan RI (2002) menjelaskan bahwa, anak dan remaja mengalami pertumbuhan sehingga memerlukan penambahan energi. Energi tambahan dibutuhkan untuk pertumbuhan tulang baru dan jaringan tubuh.

Asupan gizi juga mempunyai hubungan dengan prestasi dengan atlet, dimana asupan Gizi yang baik merupakan syarat utama untuk memperoleh kondisi tubuh yang sebaik-baiknya dan untuk mencapai prestasi yang maksimal (Sabar Surbakti, 2010). Jadi, jika kita ingin berpretasi dengan maksimal maka juga harus memperhatikan status gizi. Jika tubuh kekurangan zat gizi maka dapat berakibat pada gangguan fungsi organ, dan sistem fisiologis serta biokimiawi di dalam tubuh yaitu pada akhirnya berakibat pada penyakit. Zat gizi diklasifikasikan dalam enam kelompok besar yaitu karbohidrat, protein, lemak, vitamin, mineral, dan air. Karbohidrat, protein dan lemak disebut zat gizi makro sedangkan vitamin dan mineral disebut zat gizi mikro.

Status gizi merupakan suatu kondisi dari setiap individu yang dipengaruhi oleh penggunaan zat makanan yang di konsumsi seseorang yang merupakan indikator dari status gizinya. Anak yang memiliki status gizi yang baik tentu pertumbuhan dan perkembangannya akan berjalan seimbang dan sehat. Bila anak sudah sehat tentu dia akan melaksanakan tugasnya sehari-hari dengan baik.

\section{Motivasi Berprestasi}

Motivasi merupakan aspek psikis manusia yang mendorongnya untuk bertingkah laku.Aspek ini selalu dimiliki oleh setiap manusia untuk mencapai suatu tujuan. Dengan demikian motivasi sering diartikan sebagai daya atau kekuatan yang mendorong manusia untuk berprilaku.Selain itu motivasi adalah dorongan atau kehendak yang menimbulkan atau menyebab timbulnya semacam kekuatan

4) Suwirman. Saat ini Dosen Jurusan Pendidikan Olahraga Fakultas Ilmu Keolahragaan Universitas Negeri Padang

4) Nurul Ihsan. Saat ini Dosen Jurusan Pendidikan Olahraga Fakultas Ilmu Keolahragaan Universitas Negeri Padang

4) Sepriadi. Saat ini Dosen Jurusan Pendidikan Olahraga Fakultas Ilmu Keolahragaan Universitas Negeri Padang 
sehingga seseorang berbuat atau bertindak, dengan kata lain bertingkah laku di latar belakangi oleh suatu motif, maka dikenal dengan istilah tingkah laku bermotivasi.

Syafruddin, (2011:142) mengemukakan "motivasi adalah dorongan atau semangat yang ada dalam diri seseorang untuk sukses dalam melakukan suatu pekerjaan”. Motivasi secara umum merupakan kekuatan atau tenaga yang menimbulkan dorongan terhadap keinginan seseorang untuk melakukan sesuatu perbuatan guna memenuhi kebutuhan-kebutuhan.Berdasarkan pendapat di atas motivasi dapat diartikan sebagai salah satu faktor yang mendorong seseorang untuk melakukan aktivitas dalam rangka memenuhi kebutuhan dirinya.

Dalam melakukan aktifitas olahraga, berbagai motivasi dimiliki oleh para prilakunya sesuai dengan kebutuhannya.Ada orang yang berolahraga karena membutuhkan hidup sehat. Dengan demikian motivasinya adalah ingin hidup sehat, maka ia akan melakukan olahraga sesuai dengan tuntutan latihannya.

Berdasarkan deskripsi tentang motivasi dan prestasi sebagaimana telah dikemukakan di atas, secara umum frase motivasi berprestasi dapat diartikan sebagai aspek psikologis yang mendorong seseorang untuk memperoleh titik puncak dari kegiatan yang dilakukannya. Dalam konteks ini motivasi berprestasi cenderung bersifat internal atlet artinya motivasi-motivasi individual akan lebih berperan sebagai daya pendorong dari aktivitas olahraga yang dilakukannya.

Menurut Paul Harsey sebagaimana dalam Zuwirda (1989:14), menyatakan bahwa "motivasi berprestasi bertitik tolak dari prilaku yang diarahkan untuk mencapai prestasi terbaik (achievement oriented behavior).Tingkah laku yang diarahkan kepada hasil terbaik (standard of excellent).Tingkah laku yang diarahkan untuk berprestasi itu disebut dengan motivasi berprestasi (echievement motivation)”.

Pendapat di atas menjelaskan bahwa motivasi berprestasi merupakan suatu dorongan yang ada pada manusia untuk memenuhi kebutuhan kehidupannya.Oleh karena itu, motivasi berprestasi dapat diamati dan dapat dinilai dalam setiap kelompok yang melakukan aktivitas.Motif atau persoalan yang dapat diamati dan dinilai dalam satu aktivitas kegiatan berbeda sesuai dengan kebutuhan penilaian

4) Suwirman. Saat ini Dosen Jurusan Pendidikan Olahraga Fakultas Ilmu Keolahragaan Universitas Negeri Padang

4) Nurul Ihsan. Saat ini Dosen Jurusan Pendidikan Olahraga Fakultas Ilmu Keolahragaan Universitas Negeri Padang

4) Sepriadi. Saat ini Dosen Jurusan Pendidikan Olahraga Fakultas Ilmu Keolahragaan Universitas Negeri Padang 
tersebut. Seperti: dalam persoalan pencapaian prestasi, salah satu modusnya adalah upaya peningkatan perolehan prestasi pada masa yang akan datang.

Sedangkan Firdaus, (2012:82) menjelaskan "motivasi berprestasi adalah dorongan seseorang untuk meraih kesuksesan”. Melalui proses penilaian ini dapat diketahui orang yang memiliki motivasi berprestasi tinggi dan orang yang memiliki motivasi berprestasi rendah.

Atlet yang memiliki motivasi berprestasi tinggi dan akan tekun berlatih, berusaha dengan giat dan gigih untuk memperoleh hasil yang lebih baik, belum merasa puas atas prestasi yang telah didapatnya pada masa sebelumnya, sehingga ia selalu berusaha memperbaiki prestasinya dengan cara mengendalikan diri untuk melakukan latihan dengan sebaik-baiknya. Jika menemui hambatan dalam berlatih ia akan menggunakan segala kemampuannya untuk mengatasi kesulitan tersebut dengan mencoba menemukan sesuatu pemecahan. Selain itu atlet yang motivasi berprestasi tinggi senang untuk berlatih secara teratur bila dibandingkan dengan atlet yang memilki motivasi berprestasi rendah.

Dengan demikian atlet yang memiliki motivasi berprestasi tinggi memiliki rasa percaya diri yang tinggi serta memiliki kesediaan memikul tanggung jawab bahwa berlatih sebagai konsekwensi dari usaha untuk mencapai tujuan yang telah ditetapkan.

\section{METODOLOGI}

Penelitian yang diteliti tergolong kedalam jenis penelitian deskriptif dengan pendekatan korelasional. Subjek penelitian ini adalah siswa PPLP Sumatera Barat cabang pencak silat yang berjumlah 20 orang. Teknik penarikan sampel adalah sampling jenuh artinya seluruh subjek menjadi sampel penelitian. Data kondisi fisik diukur dengan standing board jump untuk mengukur daya ledak otot tungkai, shuttle run mengukur kelincahan, push-up mengukur daya tahan kekuatan otot lengan, sit-up mengukur daya tahan kekuatan otot perut, dan bleep test mengukur daya tahan aerobik.

4) Suwirman. Saat ini Dosen Jurusan Pendidikan Olahraga Fakultas Ilmu Keolahragaan Universitas Negeri Padang

4) Nurul Ihsan. Saat ini Dosen Jurusan Pendidikan Olahraga Fakultas Ilmu Keolahragaan Universitas Negeri Padang

4) Sepriadi. Saat ini Dosen Jurusan Pendidikan Olahraga Fakultas Ilmu Keolahragaan Universitas Negeri Padang 
Data status gizi di ukur dengan IMT (Indkes Massa Tubuh). Data motivasi berprestasi diukur dengan angket motivasi berprestasi.

Teknik analisa data yang digunakan adalah korelasi product moment oleh Pearson (Sudjana, 1996: 369).

\section{HASIL PENELITIAN DAN PEMBAHASAN}

\section{A. Hasil Pengujian Hipotesis}

Berikut ini disajikan hasil pengujian terhadap hipotesis penelitian yang telah diajukan di atas.

\section{a) Hubungan status gizi $\left(\mathrm{X}_{1}\right)$ terhadap tingkat kondisi fisik (Y) Siswa PPLP Cabang Pencak Silat Sumatera Barat \\ Analisis korelasi terhadap status gizi dengan tingkat kondisi fisik menghasilkan koefisien korelasi sebesar $\mathrm{r}_{\mathrm{xy}}=0,458$. hasil analisis dapat dilihat pada tabel di bawah ini.}

Tabel 1. Hasil Analisis Korelasi antara status gizi $\left(\mathrm{X}_{1}\right)$ terhadap tingkat kondisi fisik (Y)

\begin{tabular}{|l|l|l|l|}
\hline $\begin{array}{l}\text { Korelasi } \\
\text { Antara }\end{array}$ & $\begin{array}{l}\text { Koefisien } \\
\text { Korelasi } \\
(\mathrm{r})\end{array}$ & $\mathrm{t}_{\text {hitung }}$ & $\begin{array}{l}\mathrm{t}_{\text {tabel }} \\
\alpha=0,05\end{array}$ \\
\hline $\mathrm{X}_{1}$ dan $\mathrm{Y}$ & 0.458 & 2.19 & 1.73 \\
\hline
\end{tabular}

Berdasarkan uji keberartian korelasi antara pasangan skor status gizi terhadap tingkat kondisi fisik sebagaimana terlihat pada tabel di atas diperoleh $\mathrm{t}_{\text {hitung }}(2.19)>\mathrm{t}_{\text {tabel }}(1.73)$ pada taraf signifikansi $\alpha=0,05$ dan $\mathrm{dk}(\mathrm{n}-2=18)$. Jadi, dapat diketahui bahwa Ho ditolak dan Ha diterima. Dengan demikian terdapat hubungan yang signifikan antara status gizi dengan tingkat kondisi fisik siswa PPLP Cabang Pencak Silat Sumatera Barat.

4) Suwirman. Saat ini Dosen Jurusan Pendidikan Olahraga Fakultas Ilmu Keolahragaan Universitas Negeri Padang

4) Nurul Ihsan. Saat ini Dosen Jurusan Pendidikan Olahraga Fakultas Ilmu Keolahragaan Universitas Negeri Padang

4) Sepriadi. Saat ini Dosen Jurusan Pendidikan Olahraga Fakultas Ilmu Keolahragaan Universitas Negeri Padang 
b) Hubungan motivasi berprestasi $\left(\mathrm{X}_{2}\right)$ terhadap tingkat kondisi fisik ( $\mathrm{Y}$ ) Siswa PPLP Cabang Pencak Silat Sumatera Barat

Analisis korelasi terhadap motivasi berprestasi dengan tingkat kondisi fisik menghasilkan koefisien korelasi sebesar $r_{x y}=0,512$. Hasil analisis dapat dilihat pada tabel di bawah ini.

Tabel 2. Hasil Analisis Korelasi antara motivasi berprestasi $\left(\mathbf{X}_{2}\right)$ terhadap tingkat kondisi fisik ( $Y$ )

\begin{tabular}{|l|l|l|l|}
\hline $\begin{array}{l}\text { Korelasi } \\
\text { Antara }\end{array}$ & $\begin{array}{l}\text { Koefisien } \\
\text { Korelasi } \\
(\mathrm{r})\end{array}$ & $\mathrm{t}_{\text {hitung }}$ & $\begin{array}{l}\mathrm{t}_{\text {tabel }} \\
\alpha=0,05\end{array}$ \\
\hline $\mathrm{X}_{2}$ dan $\mathrm{Y}$ & 0.512 & 2.53 & 1.73 \\
\hline
\end{tabular}

Berdasarkan uji keberartian korelasi antara pasangan skor motivasi berprestasi terhadap tingkat kondisi fisik sebagaimana terlihat pada tabel di atas diperoleh $\mathrm{t}_{\text {hitung }}(2.53)>\mathrm{t}_{\text {tabel }}(1.73)$ pada taraf signifikansi $\alpha=0,05 \mathrm{dan} \mathrm{dk}(\mathrm{n}-$ 2=18). Jadi, dapat diketahui bahwa Ho ditolak dan Ha diterima. Dengan demikian terdapat hubungan yang signifikan antara motivasi berprestai dengan tingkat kondisi fisik Siswa PPLP Cabang Pencak Silat Sumatera Barat.

\section{B. Pembahasan}

1. Hubungan Status Gizi Terhadap Tingkat Kondisi Fisik Siswa PPLP Cabang Pencak Silat Sumatera Barat

Hasil penelitian ini menunjukan hubungan antara status gizi terhadap tingkat kondisi fisik Siswa PPLP Cabang Pencak Silat Sumatera Barat. Atlet yang memiliki status gizi yang baik cenderung memiliki kondisi fisik yang baik pula. Maka untuk meningkatkan kondisi fisik, maka asper status gizinya harus ditingkatkan.

Gizi juga dibutuhkan bagi pertumbuhan tubuh bagi seorang anak karena dengan gizi maka akan terjadi pertumbuhan tulang dan jaringan tubuh yang baik. Departemen Kesehatan RI (2002) menjelaskan bahwa, anak dan remaja mengalami

4) Suwirman. Saat ini Dosen Jurusan Pendidikan Olahraga Fakultas Ilmu Keolahragaan Universitas Negeri Padang

4) Nurul Ihsan. Saat ini Dosen Jurusan Pendidikan Olahraga Fakultas Ilmu Keolahragaan Universitas Negeri Padang

4) Sepriadi. Saat ini Dosen Jurusan Pendidikan Olahraga Fakultas Ilmu Keolahragaan Universitas Negeri Padang 
pertumbuhan sehingga memerlukan penambahan energi. Energi tambahan dibutuhkan untuk pertumbuhan tulang baru dan jaringan tubuh.

Asupan gizi juga mempunyai hubungan dengan prestasi dengan atlet. Dimana asupan Gizi yang baik merupakan syarat utama untuk memperoleh kondisi tubuh yang sebaik-baiknya dan untuk mencapai prestasi yang maksimal (Sabar Surbakti, 2010). Jadi, jika kita ingin berpretasi dengan maksimal maka juga harus memperhatikan status gizi. Jika tubuh kekurangan zat gizi maka dapat berakibat pada gangguan fungsi organ, dan sistem fisiologis serta biokimiawi di dalam tubuh yaitu pada akhirnya berakibat pada penyakit.

\section{Hubungan Motivasi Berprestasi Terhadap Tingkat Kondisi Fisik Siswa PPLP}

\section{Cabang Pencak Silat Sumatera Barat।}

Hasil penelitian ini menunjukkan bahwa terdapat hubungan antara motivasi berprestai dengan tingkat kondisi fisik Siswa PPLP Cabang Pencak Silat Sumatera Barat. Atlet yang memiliki motivasi berprestasi yang tinggi cenderung akan memiliki kondisi fisik yang baik. Oleh sebab itu, untuk meningkatkan kondisi fisik atlet, maka terlebih dahulu meningkatkan motivasi berprestasinya.

Dalam melakukan aktifitas olahraga, berbagai motivasi dimiliki oleh para prilakunya sesuai dengan kebutuhannya (Sepriadi, 2017:84). Sehingga atlit dalam melakukan aktivitas fisik ataupun latihan memiliki motivasi dalam berlatih karena berkeinginan memiliki prestasi sehingga atlit harus memiliki motivasi berprestasi.

Motivasi berprestasi dapat diartikan sebagai aspek psikologis yang mendorong seseorang untuk memperoleh titik puncak dari kegiatan yang dilakukannya. Dalam konteks ini motivasi berprestasi cenderung bersifat internal atlet artinya motivasi-motivasi individual akan lebih berperan sebagai daya pendorong dari aktivitas olahraga yang dilakukannya.

Motivasi berprestasi merupakan suatu dorongan yang ada pada manusia untuk memenuhi kebutuhan kehidupannya. Oleh karena itu, motivasi berprestasi dapat diamati dan dapat dinilai dalam setiap kelompok yang melakukan aktivitas.Motif atau persoalan yang dapat diamati dan dinilai dalam satu aktivitas

4) Nurul Ihsan. Saat ini Dosen Jurusan Pendidikan Olahraga Fakultas Ilmu Keolahragaan Universitas Negeri Padang

4) Sepriadi. Saat ini Dosen Jurusan Pendidikan Olahraga Fakultas Ilmu Keolahragaan Universitas Negeri Padang

4) Suwirman. Saat ini Dosen Jurusan Pendidikan Olahraga Fakultas Ilmu Keolahragaan Universitas Negeri Padang 
kegiatan berbeda sesuai dengan kebutuhan penilaian tersebut. Firdaus, (2012:82) menjelaskan "motivasi berprestasi adalah dorongan seseorang untuk meraih kesuksesan". Melalui proses penilaian ini dapat diketahui orang yang memiliki motivasi berprestasi tinggi dan orang yang memiliki motivasi berprestasi rendah.

\section{KESIMPULAN}

Berdasarkan hasil penelitian yang telah diuraikan dapat dikemukakan kesimpulan sebagai berikut :

1. Terdapat hubungan status gizi dengan tingkat kondisi fisik Siswa PPLP Cabang Pencak Silat Sumatera Barat

2. Terdapat hubungan motivasi berprestasi dengan tingkat kondisi fisik Siswa PPLP Cabang Pencak Silat Sumatera Barat adalah

\section{REFERENSI}

Depkes RI. 2002. Gizi Olahraga Untuk Prestasi. Jakarta.

Endang, Achdi. 2007. Gizi dan Kesehatan Masyarakat. Depok : penerbit raja Grafindo.

Firdaus, Kamal. 2012. Psikologi Olahraga. Padang: FIK UNP

Gusril. 2004. Belajar Keterampilan Motorik Pengantar Teori dan Metoda. Jakarta: DEPDIKBUD.

Harsono. 1998. Coaching dan aspek-aspek psikologis dalam coaching. Jakarta: Depdikbud Dirjen Dikti PPLPTK

Ihsan, N. (2014). The analysis of the physical condition, will pencak silat construction training center students (PPLP) of West Sumatra. In International Seminar of Sport Culture and Achievement (p. 307).

M. Sajoto, 1995. Peningkatan dan Pembinaan Kekuatan Kondisi Fisik dalam Olahraga, Semarang, Dahara Prize.

N. Ihsan, Yulkifli, Yohandri. 2017. Development of Speed Measurement System for Pencak Silat Kick Based on Sensor Technology. International Conference on Recent Trends in Physics 2016 (ICRTP2016) IOP Publishing. Journal of

4) Nurul Ihsan. Saat ini Dosen Jurusan Pendidikan Olahraga Fakultas Ilmu Keolahragaan Universitas Negeri Padang

4) Sepriadi. Saat ini Dosen Jurusan Pendidikan Olahraga Fakultas Ilmu Keolahragaan Universitas Negeri Padang

4) Suwirman. Saat ini Dosen Jurusan Pendidikan Olahraga Fakultas Ilmu Keolahragaan Universitas Negeri Padang 
Physics: Conference Series 755 (2016) 011001 doi:10.1088/17426596/755/1/011001

N.Ihsan., Yohandri, Yulkifli 2018. Instrumen Kecepatan Tendangan Pencak Silat Berbasis Teknologi. Jurnal Sosioteknologi 17 (1), 124-131 vol. 2018

Sabar Surbakti. Asupan Bahan Makanan Dan Gizi Bagi Atlet Renang. Jurnal Ilmu Keolahragaan Vol. 8 (2) Juli-Desember 2010. Medan. UNIMED

Sepriadi. 2017. Pengaruh Motivasi Berolahraga dan Status Gizi terhadap Tingkat Kebugaran Jasmani. Bali: Jurnal Penjakora. https://ejournal.undiksha.ac.id/index.php/PENJAKORA/article/view/11755

Sepriadi. Kontribusi Status Gizi dan Kemampuan Motorik terhadap Kesegaran Jasmani Siswa ekolah Dasar. Jurnal Keolahragaan. www.journal.uny.ac.id

Setyobroto, Sudibyo. 2001. Mental Training. Jakarta: Percetakan Solo 2002. Psikologi Olahraga. Jakarta: Percetakan Universitas Negeri Jakarta.

Sudjana. 1996. Metode Statistika. Bandung: Tarsito

Suhardjo. 2008. Perencanaan Pangan dan Gizi. Jakarta : Bumi Aksara

Syafruddin. 2011. Teori Kepelatihan Olahraga. Padang: UNP Press

Toho, dkk. 2004. Perkembangan Motorik Pada Anak-Anak. Jakarta: Dirjen Olahraga Departemen Pendidikan Nasional.

Zuwirda. 1989.Tesis Motivasi Berprestasi Dan Hubungan Dengan Hasil Belajar Siswa SMAINS Kayu Tanam dan SMA Negeri Sicincin. Padang: Pascasarjana: IKIP Padang

4) Nurul Ihsan. Saat ini Dosen Jurusan Pendidikan Olahraga Fakultas Ilmu Keolahragaan Universitas Negeri Padang

4) Sepriadi. Saat ini Dosen Jurusan Pendidikan Olahraga Fakultas Ilmu Keolahragaan Universitas Negeri Padang

4) Suwirman. Saat ini Dosen Jurusan Pendidikan Olahraga Fakultas Ilmu Keolahragaan Universitas Negeri Padang 